\title{
IMPRESIF BATU ALAM \\ (Sebuah Kajian Kerajinan Batu Alam di Desa Ngeposari Kecamatan Semanu Kabupaten Gunungkidul Yogyakarta)
}

\author{
Dwi Agus Susila *)
}

\begin{abstract}
ABSTRACK
Impressive is the can deliver or leave a deep impression. However, the process of making the work remains on track to exploit the advantages of natural human thought that could be the effect on the senses. In this study raised the utilization of white stones that are found in the mountainous area of Gunung. The resulting work is complete on the interior and exterior space in the form of floor tiles, wall tiles, reliefs, various masks, candle holder, decorative table, various forms of trim and flower vase

Natural stone contained in Ngeposari, Gunungkidul can we encountered along the hills that line the long and wide. In the area there are rocks that can be weighed and the community named palimanan stone white, yellow palimanan stone, stone palimanan doreng, sandstone regular Jogja, Yogya super sandstone, sandstone Jogja doreng, stone temples and stone gray green bark. The rock types by Educate Kardiyono processed and formed into products of economic value so as to raise the welfare of the surrounding community.
\end{abstract}

Keywords: Impressive, natural stone

ABSTRAK

Impresif dapat memberikan atau meninggalkan kesan yang mendalam. Namun demikian proses pembuatan karya tetap pada jalur memanfaatkan kelebihan alam pikir manusia yang bisa berupa efek pada panca inderanya. Pada kajian ini mengangkat pemanfaatan batu putih yang banyak ditemukan di pegunungan daerah Gunungkidul. Karya yang dihasilkan merupakan kelengkapan pada ruang interior dan eksterior yang berupa tegel lantai, tegel dinding, relief, aneka topeng, tempat lilin, meja hias, berbagai bentuk lis dan vas bunga.

Batu alam yang terdapat di Ngeposari, Kabupaten Gunungkidul bisa kita temui disepanjang bukit yang berderet panjang dan luas. Pada daerah tersebut terdapat batu-batuan yang bisa ditambang dan oleh masyarakat diberi nama batu palimanan putih, batu palimanan kuning, batu palimanan doreng, batu paras jogja biasa, batu paras jogja super, batu paras

* Dwi Agus Susila, Mahasiswa Program Penciptaan dan Pengkajian Pascasarjana ISI Yogyakarta 
jogja doreng, batu candi abu-abu dan batu ijo pule. Jenis batu tersebut oleh Didik Kardiyono diolah dan dibentuk menjadi produk yang bernilai ekonomi sehingga mampu mengangkat kesejahteraan masyarakat disekitarnya.

Kata Kunci: Impresif, Batu Alam.

\section{PENDAHULUAN}

Manusia sulit untuk bisa lepas dari kebutuhan ekonomi yang menyangkut masalah makanan, pakaian, tempat tinggal, alat transportasi dan seni budaya. Jika dilihat dari kebutuhan manusia dalam bidang seni dan budaya, apalagi menyangkut kreatifitas lahirnya bendabenda estetis yang memenuhi selera konsumen tentu dituntut kecerdasan emosi yang membawa alam pikir untuk berkembang. Berikut ini adalah pendapat bapak Didik Kardiyono yang mempunyai usaha UD. Mustika Alam pada tahun 1968, beliau seorang tokoh masyarakat yang tinggal di Ngeposari, Semanu, Gunungkidu dengan hasil karyanya dari bahan batu alam. "Saya bisa hidup dengan membuat produk dari bahan bangunan berbentuk tegel dengan berbagai ukuran", ide pembuatan muncul saat saya melihat begitu banyak bahan baku dari batu alam yang belum maksimal dimanfaatkan untuk menunjang kehidupan masyarakat sekitar.

Beliau berpikir keras bagaimana batu-batu tersebut bisa diwujudkan menjadi benda berharga sekaligus meningkatkan taraf hidup masyarakat disekitarnya. Bentuk tegel bukan barang satu-satunya yang bisa dibuat, itulah pemikiran yang selalu ada dibenaknya menjelang tidur. Untuk mewujudkan citacitanya, bapak Didik Kardiyono mencari informasi melaui media cetak dan elektronik yang saat itu sudah mulai berkembang dan memuat produk perajin di tanah air. Dari sumber inilah beliau mulai menemukan ide baru, desain dan contohcontoh produk yang pernah dibuat orang lain sebagai hiasan interior maupun hiasan eksterior yang ia yakini mampu menembus pasar nasional.

Pada artikel ini akan memuat perjuangan bapak Didik Kardiyono memulai usaha tegel dan kerajinan, serta bagaimana pula proses produksi terbentuk sampai beliau sukses menjalankan usaha dagangnya. Pada saat itu banyak sekali jenis batu yang bisa digunakan, yaitu batu palimanan putih, batu palimanan kuning, batu palimanan doreng, batu paras jogja biasa, batu paras jogja super, batu paras jogja doreng, batu candi abu-abu, dan batu ijo pule. Semua bahan batu tersebut mudah diperolah di daerah sekitar semanu, ponjong, karangtengah, semin dan sambeng. Bentuk batu yang berserat menarik diharapkan mampu memikat pembeli dan pencinta hasil karya kerajinan dari batu serta desainer elemen arsitektur ruang interior maupun eksterior.

Kualitas produk yang lahir dari tangan terampil putera daerah Gnungkidul diharapkan mampu menembus pasar domestik dan internasional. Sasaran produk yang mampu menembus pasar domestik antara lain kota Jakarta, 
Bandung, Surabaya, Kalimantan, Irian Jaya, dan Bali. Sedang tujuan Negara lain adalah Singapura, Malaysia, Australia, Jepang dan Negara Timur Tengah. Produk yang dibuat merupakan hasil keahlian tangan manual kecuali bentuk tegel menggunakan alat gergaji serkel dengan penggerak mesin disel. Apabila keinginan bapak Didik Kardiyono dapat terwujud, secara tidak langsung akan membawa dampak positif bagi masuknya wisatawan, para pedagang, buyer dan pertukaran desain baru yang cepat. Dari hasil kajian penelitian ini diharapkan dapat menjawab beberapa pertanyaan yang menyangkut tentang latar belakang perusahaan, bahan baku dan alat yang digunakan, desain, jenis produk yang dihasilkan, proses pembuatan dan pemasaran produk. Dengan demikian apa yang dilakukan oleh bapak Didik Kariyono adalah benar-benar sosok tokoh yang mampu menciptakan peluang kerja baru, memanfaatkan potensi alam pegunungan, memanfaatkan limbah batu besar menjadi karya kerajinan, dan mampu mengangkat Kabupaten Gunungkidul dengan desain, karya tegel, relief, bentuk lampu hias, serta motif flora dan fauna ke penjuru kota di Indonesia maupun Negara lain.

\section{PEMBAHASAN}

\section{Terbentuknya Batu Alam}

Batu alam yang ada di bumi terbentuk karena adanya proses alam yang terjadi berjuta-juta tahun yang lalu dan masih bisa kita temui sampai saat ini. Sifat khas yang ada dibatu diperoleh karena adanya perbedaan pada saat terjadi proses pembentukan. Menurut proses terjadinya dapat dibedakan menjadi tiga golongan yaitu batuan beku, batuan sedimen dan batuan metamorphic, (Departemen Perindustrian,1990/1991).

\section{Batuan Beku}

Merupakan batuan yang terbentuk karena adanya proses pengkristalan magma. Pada saat magma mengalami penurunan suhu/ pendinginan yang terjadi di dalam bumi maupun di permukaan bumi maka terjadilah pengkristalan magma. Berikut ini contoh batuan beku, yaitu Breksi, Basalt, Obsidian, Tonalite, Andesite, Kimberlite dan Pegmatile.

\section{Batuan Sedimen}

Batuan ini terjadi karena adanya proses pengendapan yang terdiri dari partikel pasir, kerikil, lempung, dan endapan lumpur. Proses alami ini berlangsung sangat lama sehingga terjadi ikatan yang erat dan semakin tertutup rapat. Menurut Joel. E. Arem, (1977), kurang lebih $75 \%$ batu-batuan yang keluar dari bumi terjadi karena adanya proses pengendapan baik di udara terbuka maupun saat terjadi da dalam air, dan kejadian ini diikuti dengan terendapnya partikel mineral di dalam air. Berikut adalah contoh batuan sedimen, yaitu Kapur, Kalsit, Arkose, Skale, Serpih, Conglomerate, Graywake dan Sandstone.

\section{Batuan Metamorphic.}

Batuan ini terbentuk karena adanya pengaruh suhu/ cuaca dan tekanan terhadap batu yang ada di permukaan bumi. Contoh batuan metamorphic adalah Marmer, Pualam, Skarn, Kuarsa, Marble, Sabak, dan Slate. Selain itu terdapat juga sifat batu-batuan, terdiri dari ukuran kekerasan, warna, kelistrikan, kemagnetan 
pada batu dan susunan kristal. Pertama adalah ukuran kekerasan, menurut Reamur ukuran kekerasan batu dimulai tahun 1722, kemudian oleh Friedrich Mohs, (1822) dari ahli minerologi Jerman mengatakan jika kekerasan batu dikelompokkan menjadi 10, yaitu:

\begin{tabular}{clc}
\hline $\begin{array}{c}\text { NO Urut Tingkat } \\
\text { kekerasan batu }\end{array}$ & Sifat/sifat tanda-tanda yang dimiliki & Contoh/ misal jenis batu \\
\hline 1 & Dapat ditekan dengan jari & Talk \\
\hline 2 & Dapat digores dengan kuku jari & Kalsit \\
\hline 3 & Dapat digores dengan kuku jari & Fluorit \\
\hline 4 & Kira-kira sekeras perunggu & Apatit \\
\hline 5 & Hampir sekeras pisau saja & Felspar \\
\hline 6 & Hampir sekeras kikir & Kuarsa \\
\hline 7 & Sekeras baja yang bagus & Korundum \\
\hline 8 & $\begin{array}{l}\text { Semua jenis baja yang keras dapat } \\
\text { digores }\end{array}$ & Intan \\
\hline 10 & Kecuali intan semua benda dapat &
\end{tabular}

Kedua adalah warna, secara umum warna batuan dapat digolongkan menjadi dua yaitu: Terang / Bening serta Semi Kabut/ Gelap dan gelap. Ketiga adalah kelistrikan, menurut Webster, (1962) terdapat sirkuit dengan rangkaian listrik oscilator. Rangkaian listrik ini dapat di gunakan untuk menentukan kandungan kuarsa pada jenis batu, serta dapat menyalakan rangkaian listrik, ada tidaknya gelombang radio, penentuan sistem radar dan rangkaian listrik pada jam. Ke empat yaitu kemagnetan pada batu, jenis batu ini bisa mempunyai daya tarik magnit yang dinyatakan dalam mg. Ke lima adalah susunan kristal batu, terdiri dari Kubik, Bersegi Enan, Belah Ketupat, Persegi Empat, Onthombic, Monoclinic, Cryto Crystalin dan Berubah-ubah.

Desain

\section{Pengertian Desain}

Desain bermanfaat untuk melihat sejauh mana persiapan produksi akan dilakukan terutama tentang produk yang akan dibuat, apakah berdasarkan pesanan maupun stok produksi pada umumnya. Menurut Merdah Hermanislamet, (1982), desain secara umum dan luas adalah sebgai hasil/produk, proses dan teknis/standar. Sedang M. Suhadji, (1973), menuliskan bahwa desain memiliki scoup yang amat luas karena di dalamnya termasuk seni, industri, maupun barangbarang kebutuhan kita sehari-hari. Mulai dari bentuknya yang sederhana, desain dibuat untuk memenuhi kebutuhan hidup manusia dengan maksud mengolah sesuatu yang mengandung rasa keindahan dan menggambarkan semangat jiwa sesuai dengan perkembangan jaman. Batasan 
yang luas dari makna desain ini diharapkan dapat dicerna dengan baik oleh perajin maupun pelaku industri kerajinan yang saat ini semakin banyak tumbuh dan berkembang di lingkungan tanah air Indonesia.

Untuk mendukung perkembangan desain yang kian maju dan modern, Bruce Archer, (1986), memberikan ketegasan tentang desain, yaitu desain memiliki batasan tertentu yang meliputi pengalaman, keterampilan dan pengetahuan yang mencerminkan kepentingan manusia dari apresiasi dan adaptasi dengan lingkungannya serta mempunyai tujuan untuk memenuhi kebutuhan hidup jasmani dan rokhani.

\section{Prinsip Desain}

Dalam mengejar hasil desain yang berkualitas diperlukan beberapa prinsip desain yang harus dipenuhi, berikut ini prinsip desain menurut Sukarman, (1982), yaitu proporsi (merupakan hubungan ukuran antara bagian-bagian terhadap keseluruhan dan antara bagian yang satu dengan bagian yang lainnya), balance/keseimbangan (merupakan suatu kualitas yang menghasilkan suatu kesamaan atau kesetaraan dalam sebuah desain), irama/ritme (adalah suatu pengalaman secara terus-menerus dan teratur dari suatu unsur-unsur), dan unity/kesatuan (yaitu suatu kesatuan kesesuaian dari elemen-elemen/unsurunsur desain satu sama lainnya yang berhubungan dengan keseluruhan, faktor termasuk juga yang ada di dalamnya).

\section{Peranan Desain}

Peranan desain dalam kegiatannya disampaikan oleh C.A. Van Poursen, yaitu suatu tindakan untuk memprakarsai suatu perubahan pada benda-benda buatan manusia. Bentuk benda ini bisa kecil, sederhana ataupun besar dengan tujuan benda tersebut diciptakan untuk memenuhi kebutuhan manusia. Oleh karena itu saat ini desain belum cukup jika hanya memandang dari faktor fungsi, bentuk, material dan ekonomi, tetapi ia juga harus mempertimbangkan sumber bahan baku, proses dan sampah ketika produk itu dibuat. Dengan demikian konsep desain yang baik adalah sudah memikirkan dampak lingkungan yang akan terjadi jika desain tersebut benar-benar diterapkan untuk dibuat produk dalam skala besar, sedang maupun kecil.

\section{Kelengkapan Alat}

\section{Alat Potong}

Alat potong batu terbuat dari plat baja yang bermata intan atau korundum. Bentuk alat potong (gergaji) berupa piringan dengan diameter 4 sampai 24 inci (10-60 cm), tebalnya $0,05 \mathrm{~cm}$ sampai 0,3 cm, Darusa Tamam, (1985). Selanjutnya disampaikan oleh Chusni Ansori dalam Penggosokan Intan dan Batu Mulia bahwa ada dua macam gergaji, yaitu Notch Rim Blades (berciri ada lubang-lubang kecil pada bagian tepi), dan Sintered Rim Blades (berciri tidak berlubang pada bagian tepi serta mempunyai daya potong lebih cepat dan halus).

\section{Alat Pembentuk}

Alat yang digunakan dalam proses membentuk adalah menggunakan gergaji mata intan dengan diameter $30 \mathrm{~cm}$ dan 40 $\mathrm{cm}$ dengan ketebalan antara $1,25 \mathrm{~cm}$ sampai $3,25 \mathrm{~cm}$, serta mempunyai tingkat kekerasan 9,5 Mohs. 


\section{Alat Penghalus}

Alat yang dipakai berbentuk amplas dengan no 100, 250 dan 1000, sedang fungsi amplas sesungguhnya adalah untuk menghaluskan permukaan batu atau benda kerja dari bekas alat pembentukan seperti gergaji dan pahat.

\section{Alat Finishing}

Alat ini bermanfaat dalam proses finishing sehingga mampu memperindah hasil produk. Alat ini terdiri dari mesin kompresor, sped dan bahan penggosok yang halus serta perlengkapan bahan untuk proses melamin atau bahan-bahan finishing sejenisnya seperti water based.

\section{Pemasaran}

\section{Pengertian Pemasaran}

Pemasaran menurut Philip Kotler adalah suatu kegiatan yang diarahkan untuk memenuhi kegiatan dan keinginan manusia melalui proses pertukaran. Sedang menurut William J. Stanton berpendapat pemasaran adalah suatu sistem keseluruhan dari kegiatan usaha yang ditujukan untuk merencanakan, menetukan harga, mempromosikan dan mendistribusikan barang dan jasa yang dapat memuaskan kebutuhan kepada pembeli yang potensial. Dengan demikian ilmu pemasaran sangat berguna untuk pengembangan dan pengenalan aset perusahaan, produk, keterampilan kerja dan pelayanan pesanan dari ranah domestik maupun luar negeri.

\section{Fungsi Pemasaran}

Fungsi pemasaran dalam suatu usaha adalah sebagai sarana promosi, pembaharu dan analisa/perencanaan/kontrol tujuan mempertahankan dengan sekaligus memperbesar jaringan usaha untuk memperoleh keuntungan yang sebesarbesarnya.

\section{Sasaran Pemasaran}

Sasaran pemasaran yang dimaksud adalah salah satu tujuan pokok yang dilakukan setiap perusahaan untuk mencapai keberhasilan program yang telah ditentukan. Sedang sasaran pemasaran di UD. Mustika Alam adalah untuk mencapai kepuasan konsumen sebesar mungkin dan untuk memaksimalkan konsumsi barang apapun yang diproduksi, baik berdasarkan pesanan maupun produksi yang bersifat rutinitas.

\section{E. Proses Perwujudan Karya}

\section{Sketsa Alternatif}

Kegiatan ini berfungsi untuk memilih dari sekian banyak ide yang muncul pada konseptor, karena tanpa adanya sketsa alternatif tidak mungkin menemukan sketsa terpilih atau sketsa terbaik yang kemudian disempurnakan menjadi sebuah gambar kerja untuk direncanakan menjadi produk sesungguhnya. Sumber ide sketsa alternatif bisa muncul dari bentuk benda di sekitar kita seperti bentuk daun, ranting, pohon, buah, alat transportasi (mobil, sepeda, gerobak, kereta kuda, becak dll), binatang darat/laut dan udara. Semua benda yang dirakit manusia dan benda alam ciptaan Tuhan adalah keberagaman yang menjadi sumber penciptaan karya yang tidak akan habis untuk digali. Tinggal bagaimana desainer mengolah dan mengkomper semua persediaan tadi menjadi konsep karya yang menarik untuk dibuat sekaligus dinikmati oleh pecinta seni. 


\section{Pemilihan Bahan}

Pemilihan bahan dilakukan untuk memilih, menyeleksi bahan batu yang akan diterapkan untuk sebuah produk, meliputi jenis batu yang sesuai dengan karakter desain, besar kecilnya bahan baku, cacat atau tidak pada bahan batu, serat dan warna yang muncul pada bahan batu tersebut.

\section{Pemotongan}

Ketika batu yang akan digunakan sudah terseleksi dengan baik, langkah selanjutnya adalah pemotongan memakai mesin potong/circle dengan penggerak mesin disel. Pada tahap ini batu dibentuk sesuai dengan kebutuhan desain atau pemesan, hal ini untuk menghindari kerugian yang ditimbulkan oleh kesalahan pemotongan bahan baku batu tersebut. Agar hasil potong bahan batu halus dan tidak rusak, sebaiknya ketika memotong keadaan gergaji selalu dalam keadaan dingin atau basah dengan cara diberi air yang mengalir ke arah mata gergaji.

\section{Pembentukan}

Pada proses pembentukan bahan tegel memakai gergaji potong bermata intan sesuai dengan kebutuhan dan ukuran, sedang pembentukan desain lain seperti hiasan patung, fentilasi, hiasan dinding, relief dan lainnya menggunakan teknik pahat manual yang mengandalkan kreatifitas perajin. Ketika pembentukan dimulai sebaiknya tenaga kerja selalu melihat desain atau prototype yang telah disiapkan, sehingga hasil akhir sesuai dengan perencanaan.

\section{Penghalusan}

Merupakan tindakan untuk membuat kesan halus pada benda kerja, hal ini bisa dilakukan dengan menggunakan amplas dengan nomer tertentu sesuai kebutuhan. Cara menghaluskan yang baik adalah searah dengan tujuan tidak merusak hasil akhir pada batu atau hasil karya. Sedang amplas yang sering digunakan yaitu no 100, 250, dan 1000 .

\section{Finishing}

Finishing adalah proses terakir pada pembuatan suatu produk, berfungsi untuk memberi lapisan dengan melamin atau bahan-bahan sejenisnya sehingga produk bisa lebih tahan terhadap cuaca, hama dan menambah daya tarik. Saat ini ada juga yang menggunakan bahan finishing water based dengan pengencer air. Langkah finishing ini dilakukan apabila produk tidak mengalami proses kerja yang lain, sehingga alur kerja sesuai dengan SOP (Standar Operasional Prosedur).

\section{F. Hasil Produk}

Berikut ini merupakan tampilan hasil produksi di UD. Mustika Alam dan kelengkapan alat yang selama ini dibuat untuk memenuhi kebutuhan konsumen. Banyak hal yang bisa dilakukan oleh perusahaan untuk menarik pemesan, diantaranya memberikan servis atau pelayanan yang memuaskan, memberi bonus dan potongan harga. Berikut ini adalah data dari gambar yang diperoleh: 


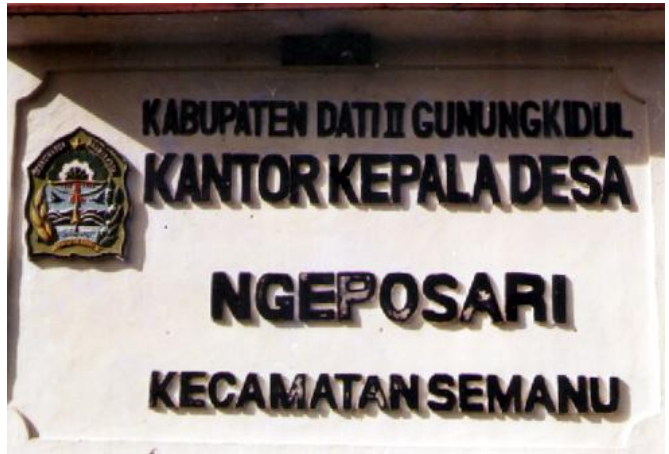

Gambar 1.Papan Nama UD. Mustika Alam di Mojo, Ngeposari, Semanu, Gunungkidul,

D. I. Yogyakarta. (Foto: Dwi Agus. S, 1999)

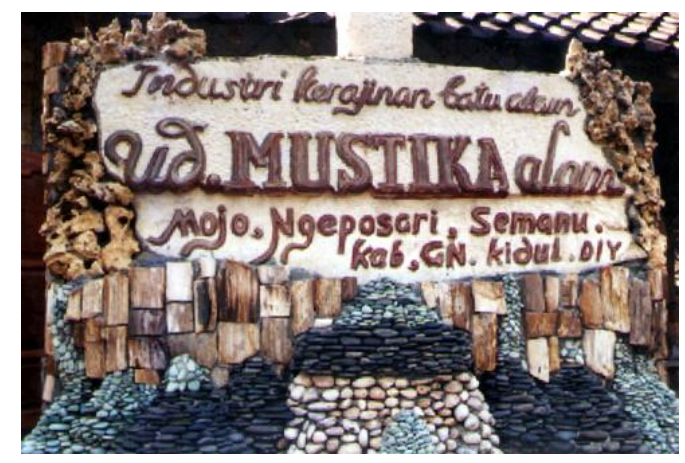

Gambar 3. Papan nama Industri Kerajinan Batu Alam UD. Mustika Alam di Mojo, Ngeposari, Semanu, Gunungkidul, D. I. Yogyakarta.

(Foto: Dwi Agus. S, 1999)

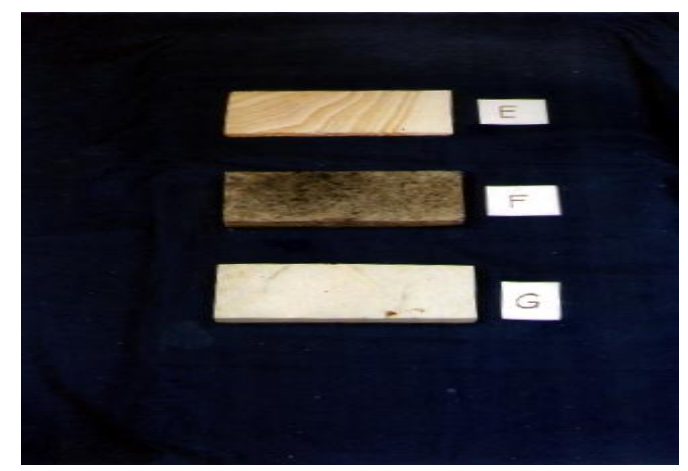

Gambar 5. Keterangan: E. Batu Paras Jogja Doreng, F. Batu Candi Abu-abu, G. Batu ljo Pule. (Foto: Dwi Agus. S, 1999)

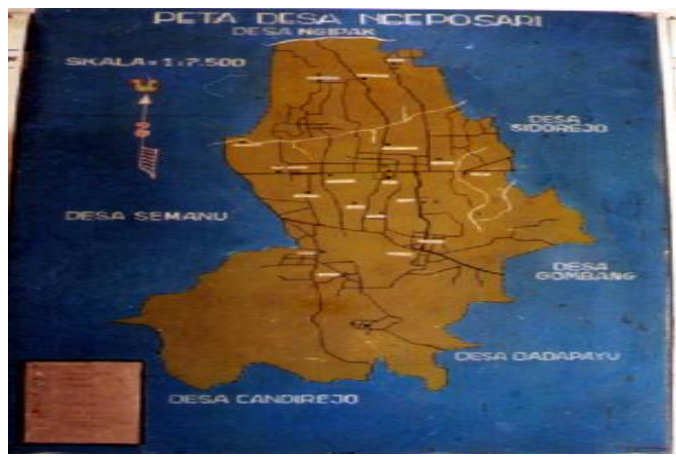

Gambar 2. Peta Desa Ngeposari, merupakan letak daerah penelitian.

(Foto: Dwi Agus. S, 1999)

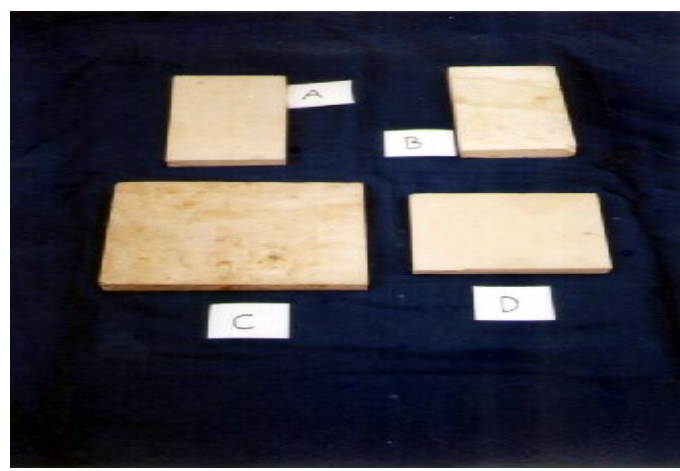

Gambar 4. Bahan Baku dari Batu Putih, keterangan: A. Batu Palimanan Putih, B. Batu

Palimanan Kuning/ doreng, C. Batu Paras Jogja Biasa, D. Batu Paras Jogja Super.

(Foto: Dwi Agus. S, 1999)

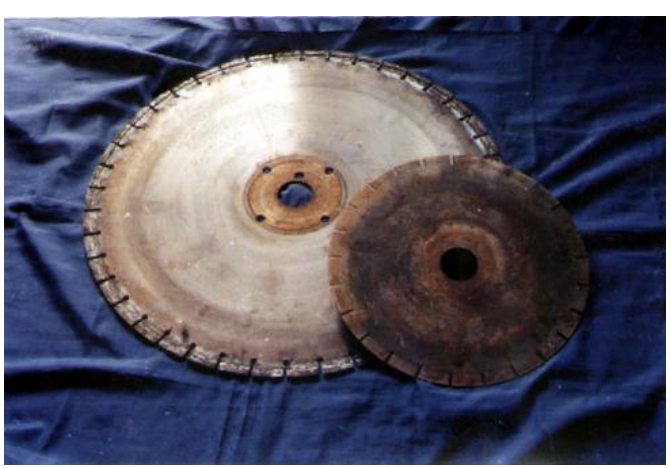

Gambar 6. Contoh mata gergaji bermata intan, terbuat dari besi baja diameter $30 \mathrm{sd} 50 \mathrm{~cm}$ dan berfungsi untuk membelah/memotong batu berbentuk bongkahan. (Foto: Dwi Agus. S, 1999) 


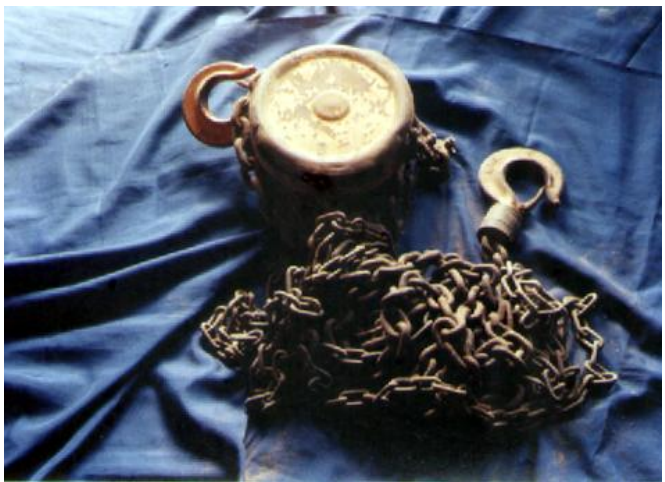

Gambar 7. Alat derek, berfungsi untuk mengangkat batu berukuran besar.

(Foto: Dwi Agus. S, 1999)

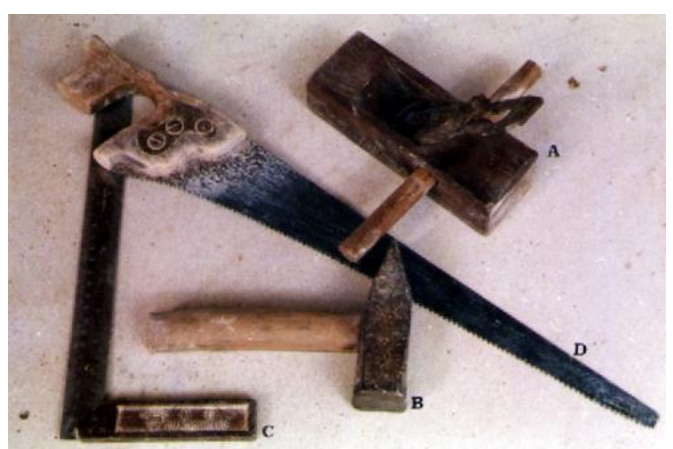

Gambar 9. Alat manual, A. Ketam, B. Palu, C. Siku, D. Gergaji Tangan.

(Foto: Dwi Agus. S, 1999)

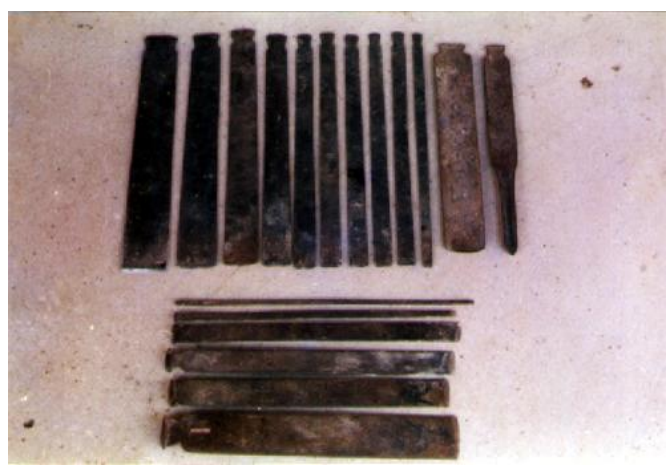

Gambar 11. Pahat ukir, berfungsi untuk membentuk kesan relief, tinggi dan rendah sesuai konsep desain.(Foto: Dwi Agus. S, 1999)

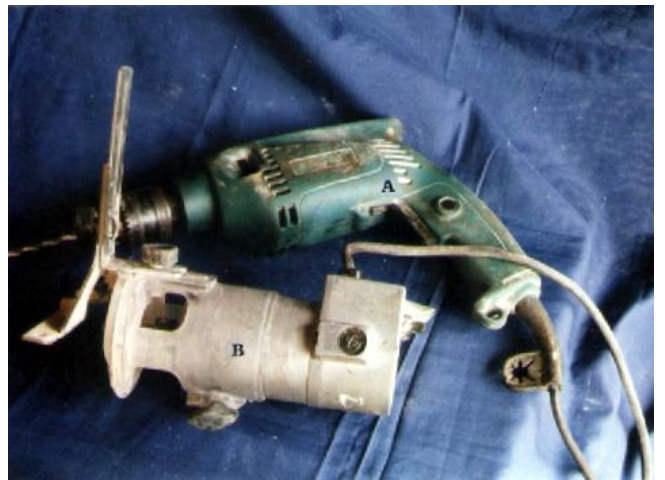

Gambar 8. A. Alat mesin bor listrik, (untuk mempercepat pembuatan lobang), B. Alat mesin router, (untuk membuat bentuk profil).

(Foto: Dwi Agus. S, 1999)

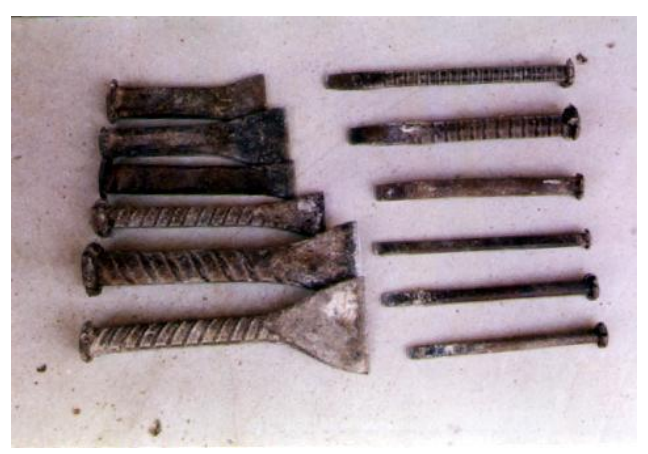

Gambar 10. Pahat cuplik, berfungsi untuk pembentukan global maupun setengah jadi. (Foto: Dwi Agus. S, 1999)

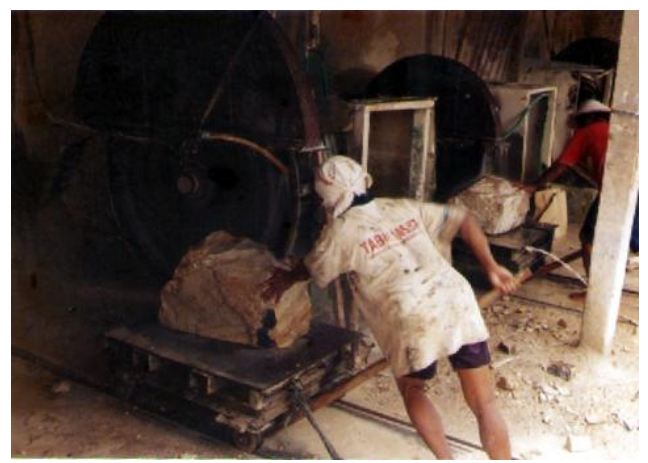

Gambar 12. Proses pemotongan dan pembelahan. (Foto: Dwi Agus. S, 1999) 


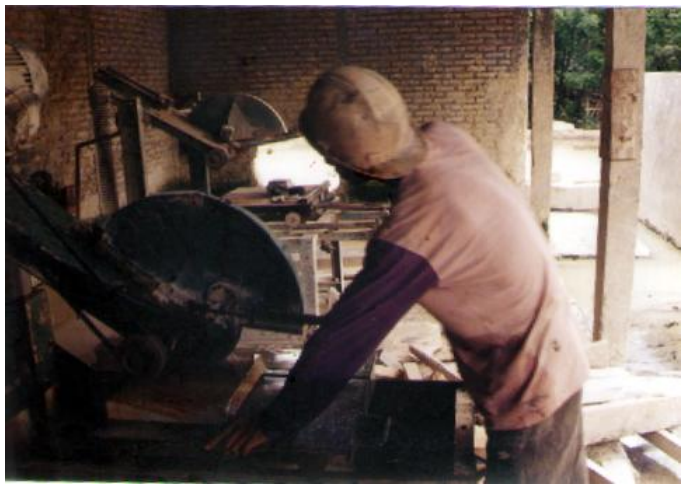

Gambar 13. Proses pembentukan tegel.

(Foto: Dwi Agus. S, 1999)

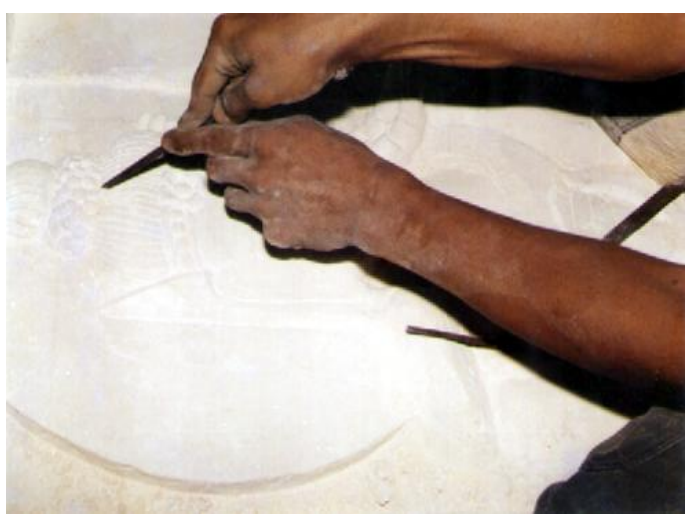

Gambar 15. Proses pembuatan relief ganesha. (Foto: Dwi Agus. S, 1999)

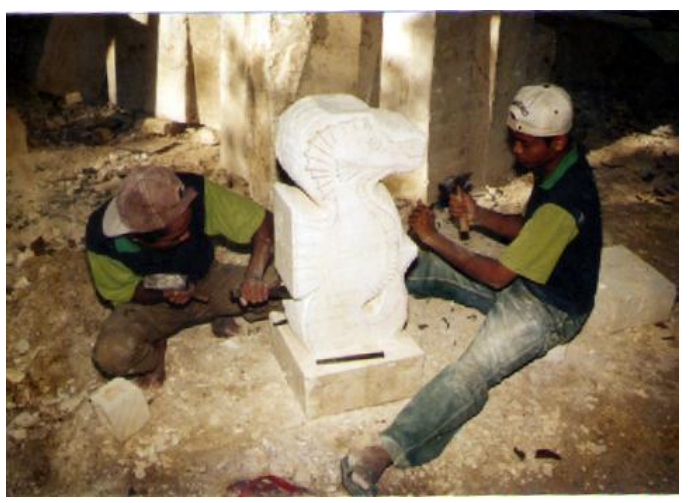

Gambar 17. Proses pembuatan kuda laut. (Foto: Dwi Agus. S, 1999)

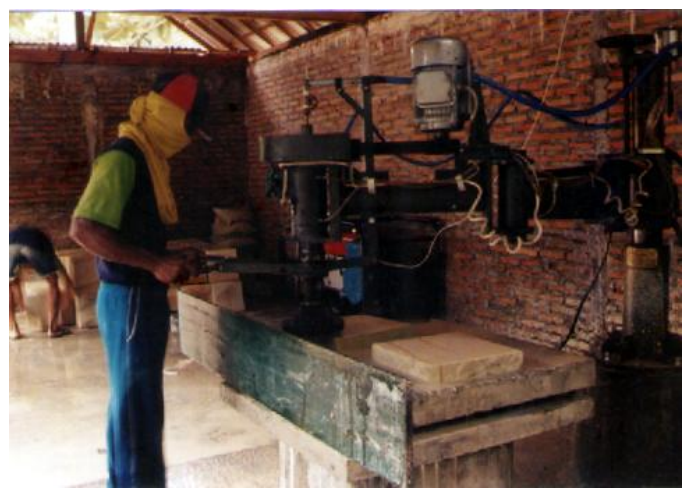

Gambar 14. Proses penghalusan tegel dengan mesin pemoles. (Foto: Dwi Agus. S, 1999)

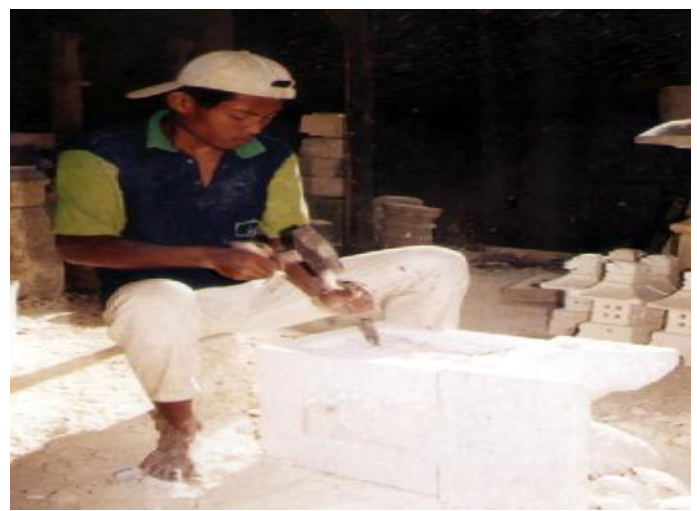

Gambar 16. Proses pembuatan tempat lampu taman. (Foto: Dwi Agus. S, 1999)

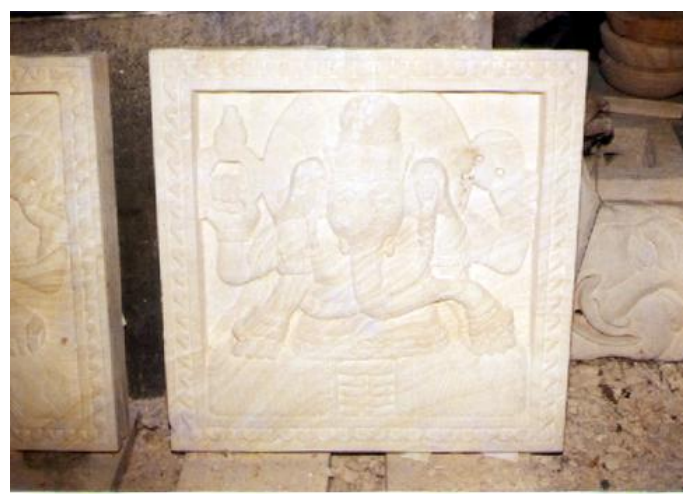

Gambar 18. Jenis Produk: Relief Ganesha, Ukuran: $80 \times 80 \times 10 \mathrm{~cm}$, Bahan: Batu paras jogja super, Finishing: Water Based (natural/asli warna batu), Harga: Rp. 500.000,-, Fungsi: Benda hias. (Foto: Dwi Agus. S, 1999) 


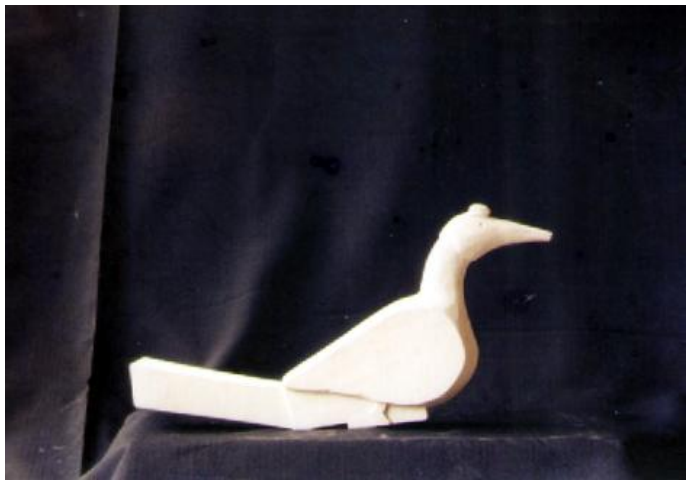

Gambar 19. Jenis Produk: Patung Burung, Ukuran: 40x18x7 cm, Bahan: Batu palimanan putih, Finishing: Water Based (natural/asli warna batu), Harga: Rp. 17.000,-, Fungsi: Benda hias. (Foto: Dwi Agus. S, 1999)

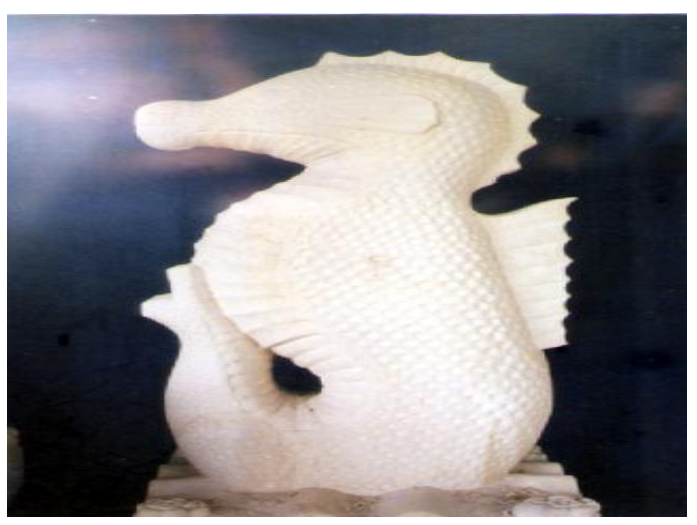

Gambar 21. Jenis Produk: Kuda Laut, Ukuran: 93×36×36 $\mathrm{cm}$, Bahan: Batu palimanan putih, Finishing: Water Based (natural/asli warna batu), Harga: Rp. 500.000,-, Fungsi: Benda hias.(Foto: Dwi Agus. S, 1999)

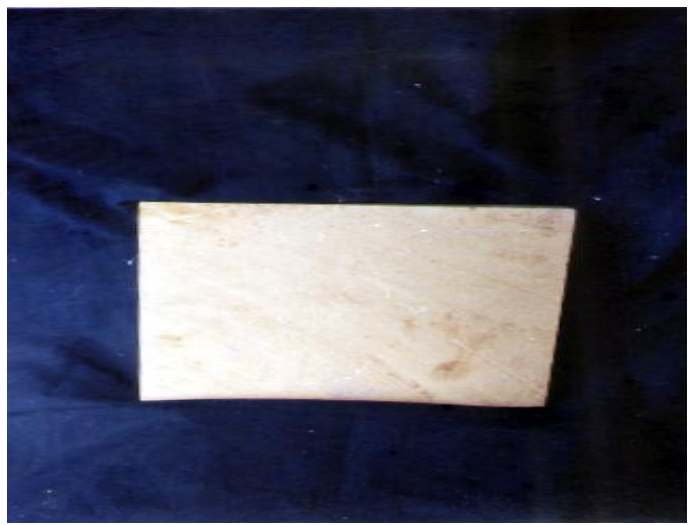

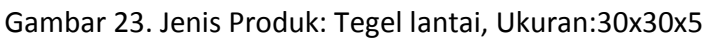
$\mathrm{cm}$, Bahan: Batu candi abu-abu, Finishing: Water Based (natural/asli warna batu), Harga: Rp. 30.000,-/m2, Fungsi: Benda pakai. (Foto: Dwi Agus. S, 1999)

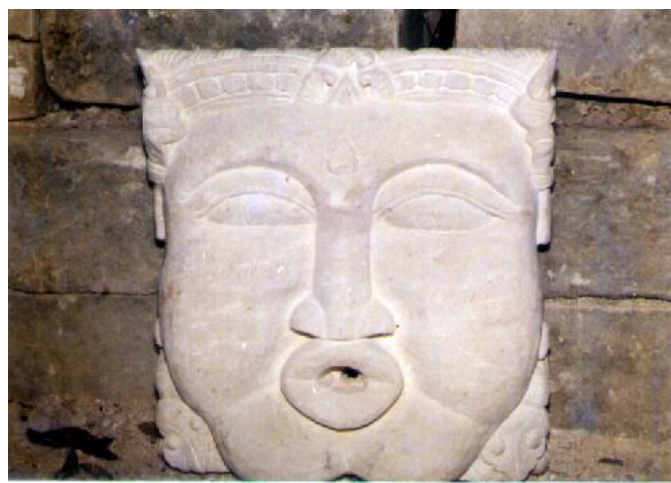

Gambar 20. Jenis Produk: Topeng, Ukuran: 40x40x40 cm, Bahan: Batu palimanan putih, Finishing: Water Based (natural/asli warna batu), Harga: Rp. 50.000,-, Fungsi: Benda hias. (Foto: Dwi Agus. S, 1999)

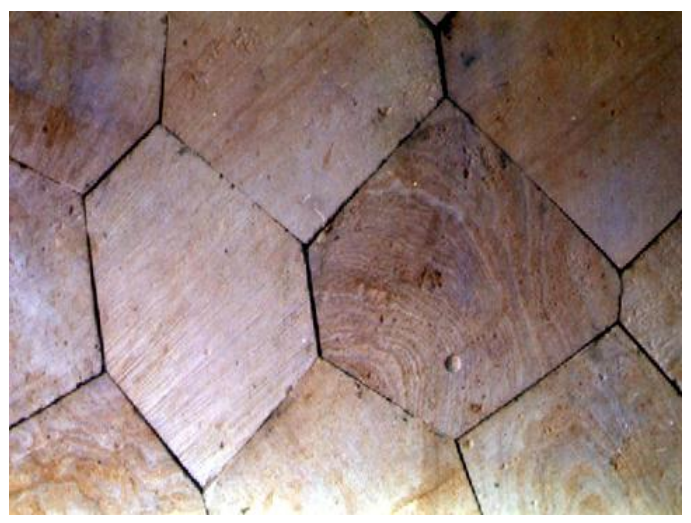

Gambar 22. Jenis Produk: Tegel dinding, Ukuran: $100 \times 100 \times 3 \mathrm{~cm}$, Bahan: Batu palimanan doreng, Finishing: Water Based (natural/asli warna batu), Harga: Rp. 25.000,/m2, Fungsi: Benda pakai.

(Foto: Dwi Agus. S, 1999)

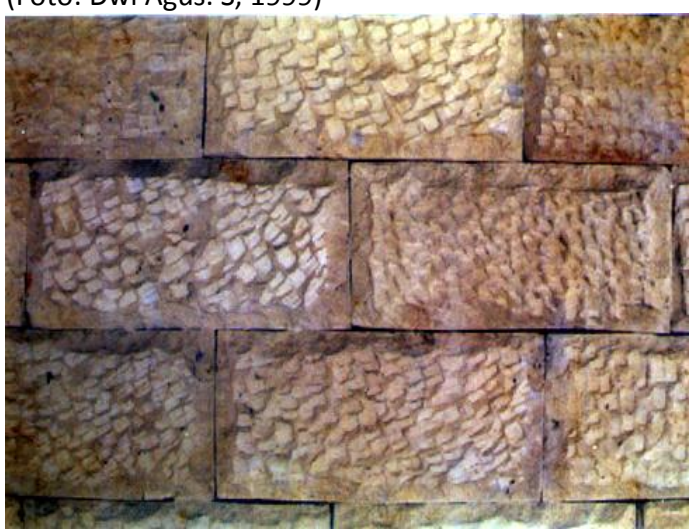

Gambar 24. Jenis Produk: Tegel dinding, Ukuran:

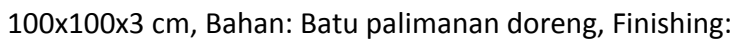
Water Based (natural/asli warna batu), Harga: Rp. 25.000,/m2, Fungsi: Benda pakai.

(Foto: Dwi Agus. S, 1999) 


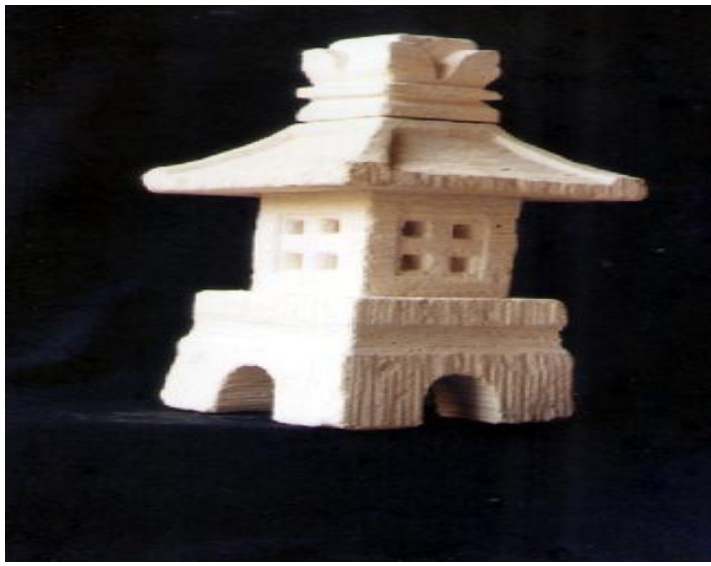

Gambar 25. Jenis Produk: Tempat lampu taman, Ukuran: 38×19×19 cm, Bahan: Batu palimanan kuning, Finishing: Water Based (natural/asli warna batu), Harga: Rp. 35.000,- Fungsi: Benda pakai.

(Foto: Dwi Agus. S, 1999)

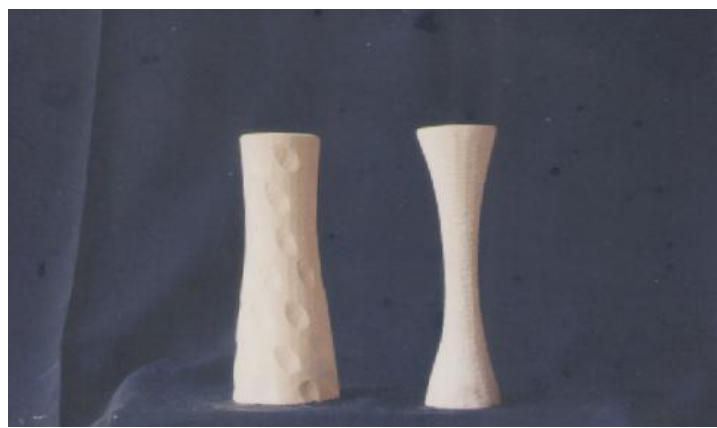

Gambar 27. Jenis Produk: Tempat lilin, Ukuran:

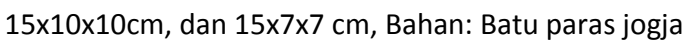
doreng, Finishing: Water Based (natural/asli warna batu), Harga: Rp. 15.000,-, Fungsi: Benda pakai. (Foto: Dwi Agus. S, 1999)

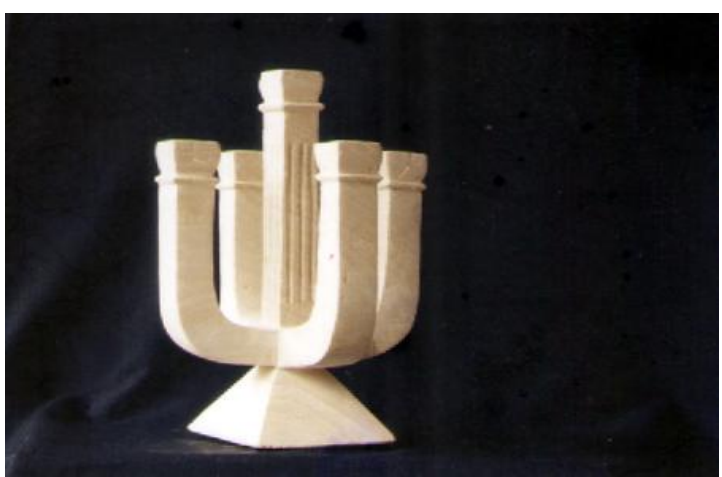

Gambar 29. Jenis Produk: Tempat lilin, Ukuran: $30 \times 25 \times 25 \mathrm{~cm}$, Bahan: Batu paras jogja biasa, Finishing: Water Based (natural/asli warna batu), Harga: Rp. 35.000,-, Fungsi: Benda pakai. (Foto: Dwi Agus. S, 1999)

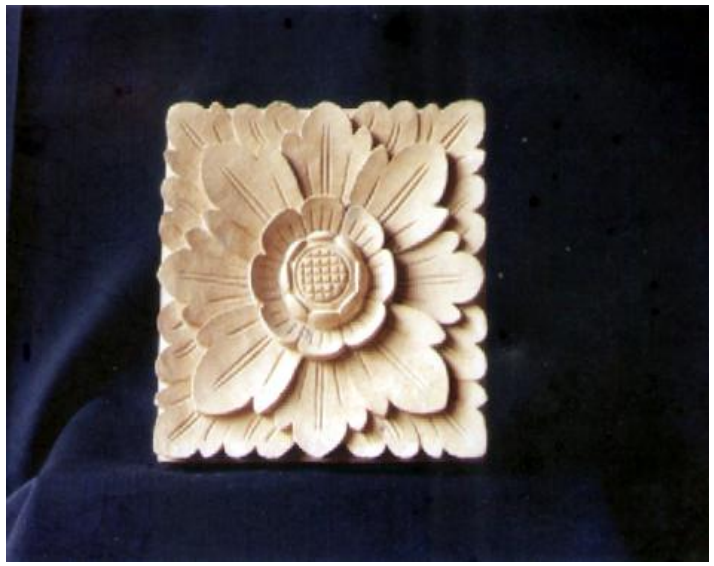

Gambar 26. Jenis Produk: Tempat lampu taman, Ukuran: 38×19×19 cm, Bahan: Batu palimanan doreng, Finishing: Water Based (natural/asli warna batu), Harga: Rp. 35.000,, Fungsi: Benda pakai.

(Foto: Dwi Agus. S, 1999)

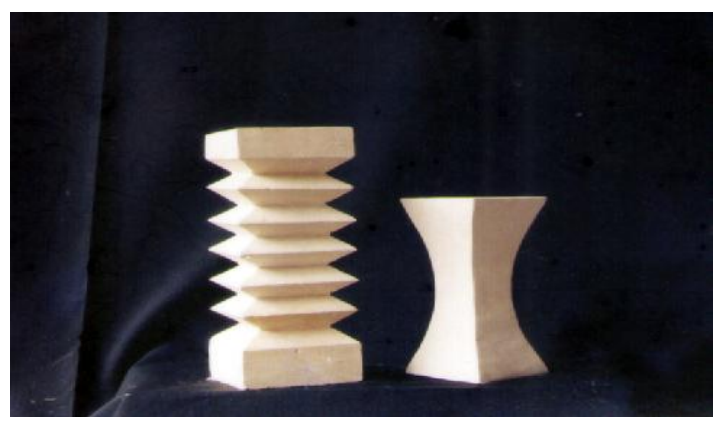

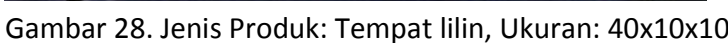

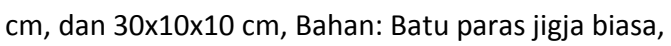
Finishing: Water Based (natural/asli warna batu), Harga: Rp. 15.000,-, Fungsi: Benda pakai.

(Foto: Dwi Agus. S, 1999)

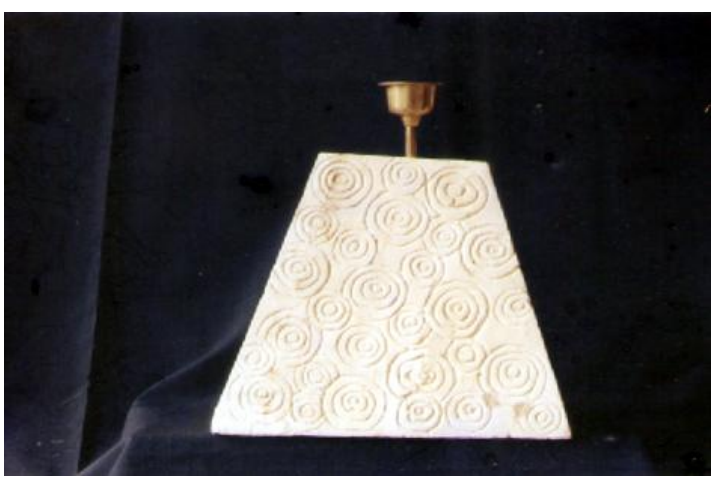

Gambar 30. Jenis Produk: Tempat lampu tidur,Ukuran: $38 \times 25 \times 25 \mathrm{~cm}$, Bahan: Batu paras jogja super, Finishing: Water Based (natural/asli warna batu), Harga: Rp. 35.000,, Fungsi: Benda pakai (Foto: Dwi Agus. S, 1999) 


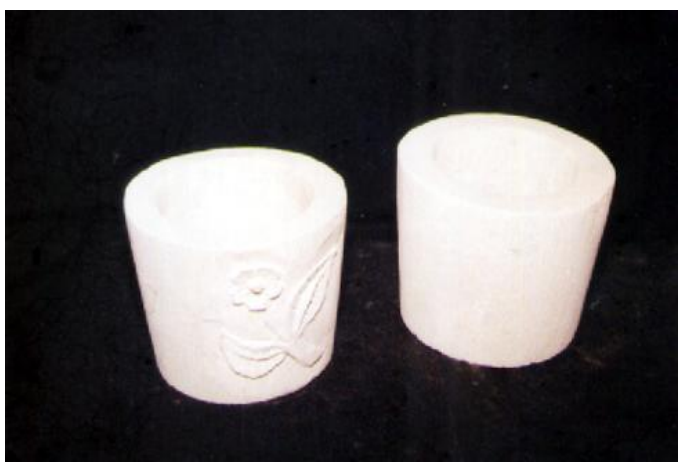

Gambar 31. Jenis Produk: Tempat abu, Ukuran: $10 \times 10 \times 10 \mathrm{~cm}$ Bahan: Batu palimanan putih, Finishing: Water Based (natural/asli warna batu), Harga: Rp. 7.500,-, Fungsi: Benda pakai.(Foto: Dwi Agus. S, 1999)

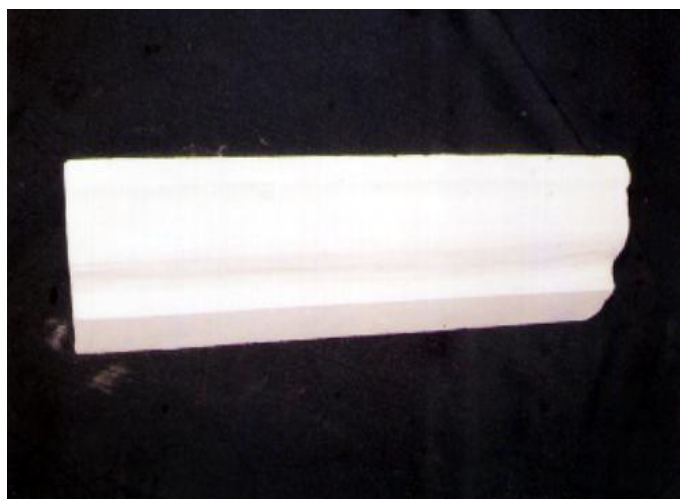

Gambar 33. Jenis Produk: Profil/lis,Ukuran: $38 \times 10 \times 10 \mathrm{~cm}$, Bahan: Batu palimanan putih, Finishing: Politur, Harga: Rp. 10.000,-, Fungsi: Benda pakai. (Foto: Dwi Agus. S, 1999)

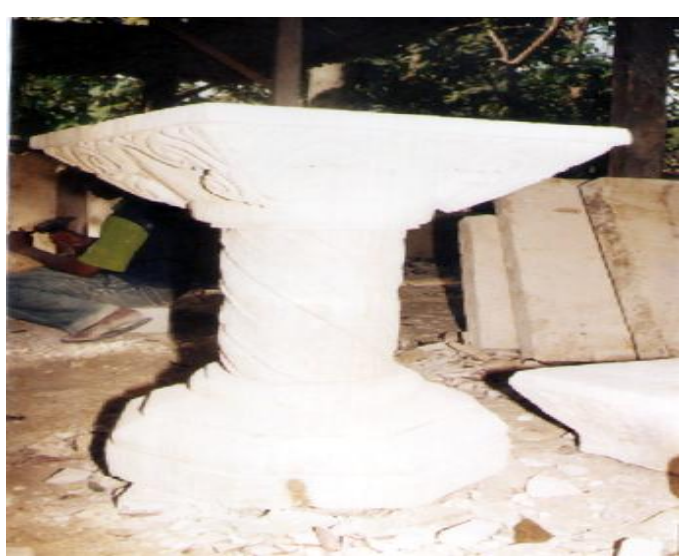

Gambar 35. Jenis Produk: Meja hias, Ukuran: $80 \times 50 \times 50 \mathrm{~cm}$, Bahan: Batu paras jogja biasa, Finishing: Water Based (natural/asli warna batu), Harga: Rp. 350.000,-, Fungsi: Benda pakai. (Foto: Dwi Agus. S, 1999)

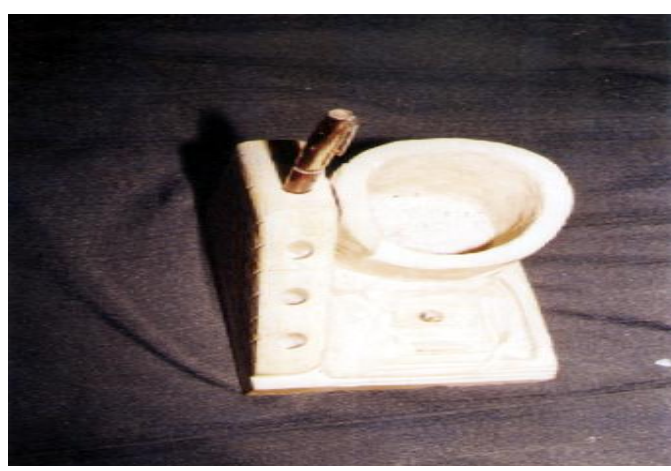

Gambar 32. Jenis Produk: Tempat pensil,Ukuran: $14 \times 14 \times 13$ $\mathrm{cm}$, Bahan: Batu palimanan kuning, Finishing: Politur, Harga: Rp. 15.000,-, Fungsi: Benda pakai.

(Foto: Dwi Agus. S, 1999)

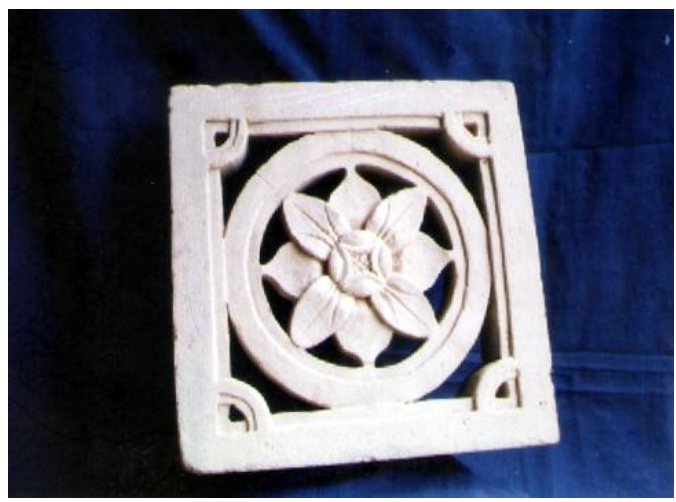

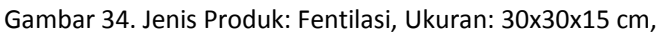
Bahan: Batu palimanan kuning, Finishing: Melamin, Harga: Rp. 20.000,-, Fungsi: Benda pakai .

(Foto: Dwi Agus. S, 1999)

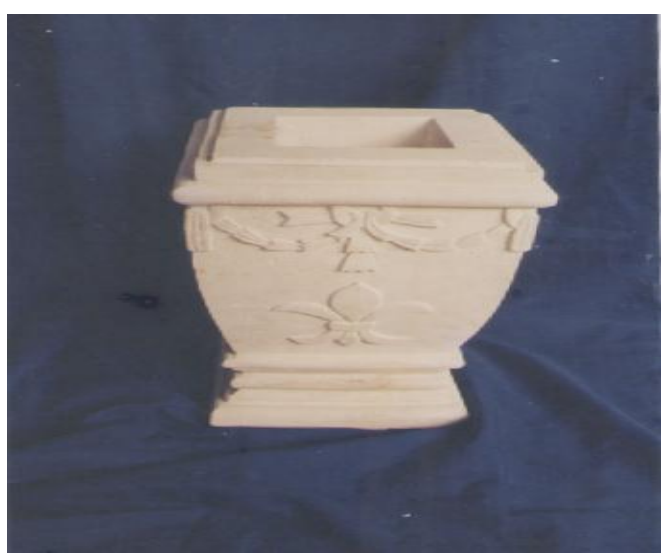

Gambar 36. Jenis Produk: Tempat bunga, Ukuran: 40×25×25 $\mathrm{cm}$, Bahan: Batu palimanan putih, Finishing: Water Based (natural/asli warna batu, Harga: Rp. 60.000,-, Fungsi: Benda pakai . (Foto: Dwi Agus. S, 1999) 
Jika diamati dengan cermat semua produk yang dibuat merupakan benda pakai dan hias yang digunakan untuk kelengkapan ruang interior dan eksterior pada rumah tangga, restoran maupun hotel. Produk ini sangat menarik karena dibuat dari batu alam yang menyimpan keindahan alami/natural, sekaligus memanfaatkan potensi alam yang sangat besar di daerah Gunungkidul. Dengan banyaknya perajin dan desain yang berkembang, maka semakin banyak pula peluang untuk menciptakan lapangan kerja bagi masyarakat sekitar. Oleh karena itu kekuatan ekonomi pada masyarakat akan semakin kuat, majudan berkembang.

\section{PENUTUP}

Sesuai data yang diperoleh di UD. Mustika Alam yang dikelola oleh bapak Didik Kardiyono dalam bidang kerajinan batu alam, maka perusahaan yang mengolah batu putih menjadi produk kerajinan yang bernilai seni ini dapat dikatakan berhasil untuk mengangkat ekonomi masyarakat di daerah Ngeposari, Semanu, Gunungkidul. Dengan melihat kelengkapan alat yang masih tradisional tetapi sudah didukung mesin yang cukup modern, maka perusahaan ini masuk dalam taraf berkembang. Untuk menjadikan lebih maju lagi diperlukan usaha pendamping dari pemerintah daerah Gunungkidul atau organisasi yang peduli pada usaha kecil dan menengah. Apabila semua komponen yang terkait mampu meningkatkan keahlian atau keterampilan perajin dan alat produksinya, bukan tidak mungkin kemajuan perusahaan akan tercapai dan masyarakat ikut sejahtera.

Pemakaian bahan baku yang cukup lama akan mengganggu ekosistem lingkungan hidup, tetapi dengan pengendalian pertambangan yang diorganisasi dengan baik akan mampu menghindari kerusakan lingkungan hijau. Proses produksi yang dilakukan di UD. Mustika Alam selalu ada hubungannya dengan lingkungan dan masa depan masyarakatnya, karena menyangkut dari unsur penambang, transportasi, perajin, produksi, pekejing, dan pemasaran dilakukan oleh penduduk asli Gunungkidul. Jenis produk dan desain yang dibuat mengacu pada potensi pasar dan pesanan yang rutin terjadi. Hal ini ada kaitannya dengan pemasaran yang dilakukan dengan cara menjual produk langsung ke konsumen, melalui agen/pengepul, serta bayer yang kontak secara langsung. Agen utama adalah Bali karena mempunyai wilayah yang strategis untuk transaksi pasar baik dalam maupun luar negeri. Dengan perkembangan yang cukup pesat dan didukung arus teknologi yang modern, promosi melalui pameran dan dunia maya wajib dilakaukan oleh perusahaan. Untuk itu diperlukan sumber daya manusia yang handal agar mampu mengolah kegiatan produksi, stok barang, manajemen keuangan dan promosi yang lebih efektif/professional sehingga mampu bersaing dengan pengusaha lainnya. 


\section{KEPUSTAKAAN}

C.A., Van Poursen, Strategi Kebudayaan, Kanisius.

Departemen Pendidikan dan Kebudayaan Kamus Besar Bahasa Indonesia, Balai Pustaka, 1989.

Gustami, SP (1991), Seni Kriya Indonesia Dilema Pembinaan dan Pengembangannya, Jurnal Seni No: 1, (Yogyakarta), (3 Oktober)

Hermanislamet, Merdah (1982), Memasyarakatkan dan Membudayakan Desain, Majalah Sani, $X$, (September )

Kotler, Philip (1985), Penterjemah: Ellen Gunawan, Manajemen Pemasaran, Edisi IV, Jakarta.

M. Suhadji, (1982), Peranan Design dalam Perkembangan Industri dan Kerajinan, Majalah Sani, VIII, (September).

Pengembangan Teknologi Proses Batu Mulia sebagai Bahan Baku Perangkat Busana, (Yogyakarta: Laporan Proyek Penelitian dan Pengembangan Industri, Kerajinan dan Batik, Departermen Perindustrian, 1990/1991).

Sachari, Agus (1986), Editor, Paradigma Desain Indonesia,Kelompok Studi Desain, Jurusan Desain IT.
Swasta, Basu (1979), Azas-azas Marketing, Edisi II, (Yogyakarta: Liberty).

Warwick Rodney Purser, (1998), Kedaulatan Rakyat, (Yogyakarta), 24 Oktober, Ke LIV, kol 4.

Tamam, Darusa (1985), Penggosokan Intan dan Batu Mulia, (Djakarta: PT. Indira.)

T.G.S., Mulia dan K.A.H.,Hidding, Ensiklopedi Indonesia, Bandung: Penerbit W. Van Houve, $t$ th.

\section{NARASUMBER:}

Didik Kardiyono, pelaku usaha kerajinan batu alam, bertempat tinggal di Mojo, Ngeposari, Semanu, Gunungkidul, Daerah Istimewa Yogyakarta 